\title{
Effects of Glucose and Ferrous Supplements and Culture Conditions on Lipopeptide Biosurfactant from Pseudomonas spp.
}

\author{
Thanawat Choopraserdchok, Dusit Athinuwat, and Pumnat Cheunchomrat
}

\begin{abstract}
To enhance lipopetide biosurfactant production by Pseudomonas spp., the effects of medium and culture conditions were investigated. Nutrient broth (NB) supplemented with glucose and molasses as carbon sources were used to increase biosurfactant yield. Cultivation temperatures and initial $\mathbf{p H}$ were also studied. In this experiment, NB was used as a control to produce biosurfactant with the yield of $0.58 \mathrm{~g} / \mathrm{L}$. The lipopeptide biosurfactant yield was increased to $2.76 \mathrm{~g} / \mathrm{L}$ when Pseudomonas spp. was cultured in NB supplemented with $1 \%$ w/v glucose, $500 \mu \mathrm{M}$ FeSO4, pH 9.0 and cultivation of $20^{\circ} \mathrm{C}$ for $72 \mathrm{~h}$. Its specific growth rate was 0.25 h-1.
\end{abstract}

Index Terms-Pseudomonas spp., lipopeptide biosurfactant, glucose, ferrous.

\section{INTRODUCTION}

Surfactants consist of hydrophilic and hydrophobic moieties. According to their compositions, surface tension is able to be decreased by surfactants. These compounds play many rolls of human life in many fields not only agricultural, cosmetic, pharmaceutical applications, but also in food industries [1]. However, the synthetic chemical surfactants are toxic and difficult to degrade [2].

Biosurfactants are biological surface active compounds. Biosurfactants are produced by many living organisms, especially microorganisms. They are classified into 4 groups based on their chemical structures; glycolipids, lipopeptides, phospholipids and fatty acids, and polymeric biosurfactants [3]. In addition, biosurfactants exhibit important properties such as antimicrobial activity, anti-adhesion of microorganisms, biodegradability, emulsifying agents, and low toxicity. Therefore, biosurfactants have potentially applied in environmental, food industrial, agricultural, therapeutic and biomedical applications [1], [4].

To enhance biosurfactant yield, medium and culture conditions are investigated. Mouafi et al. [1] reported that lipopeptide biosurfactant production from Bacillus brevis was increased by glucose supplementation in medium. The lipopeptide biosurfactant yield of Bacillus subtilis B20 was

Manuscript received September 11, 2017; revised November 9, 2017

Thanawat Choopraserdchok and Pumnat Cheunchomrat are with the Department of Food Science and Technology, Faculty of Science and Technology, Thammasat University, Rangsit Campus, Pathum Thani, 12121 Thailand (e-mail: cpumnat@tu.ac.th).

Dusit Athinuwat is with the Department of Agricultural Technology, Faculty of Science and Technology, Thammasat University, Rangsit Campus, Pathum Thani, 12121 Thailand. increased to $2.29 \mathrm{~g} / \mathrm{L}$ when cultured with molasses [5] Karanja oil was also able to increase the biosurfactant yield of Pseudomonas aeruginosa KVD-HR42 to $5.90 \mathrm{~g} / \mathrm{L}$ [3].

Trace elements are important for bacterial growth by acting as co-factors for enzymes. The effect of metal ion concentration on biosurfactant production was studied by [6]. Kiran et al. [7] reported that iron concentration in culture medium was the critical factor on biosurfactant production by Brevibacterium aureum MSA13. Moreover, Surfactin, the lipopeptide biosurfactant from Bacillus subtilis ATCC 21332, was increased to approximately $3000 \mathrm{mg} / \mathrm{L}$, when iron sulfate was added into culture medium [6].

Culture temperature and $\mathrm{pH}$ of culture medium are also affected to biosurfactant production. The biosurfactant yield from Pseudomonas sp. was increased after cultivation with optimal pH and temperature [3]. Moreover, Hemtala et al. [8] reported that culture temperature and $\mathrm{pH}$ was also the factor to enhance biosurfactant yield from Stenotrophomonas maltophilia NBS-11.

In this study, medium was investigated to enhance lipopeptide biosurfactant yield from Pseudomonas spp. by supplement nutrient broth (NB) with glucose and molasses as carbon sources and metal ion of ferrous. The effects of temperature and $\mathrm{pH}$ on biosurfactant yield were also studied.

\section{MAterials AND MethodS}

\section{A. Microorganism and Inoculum Preparation}

The microorganism Pseudomonas spp. was screened and studied from previous study [9]. This strain produced lipopeptide biosurfactant. The biosurfactant producing bacteria was kept in $20 \%$ glycerol solution and maintained at $-20^{\circ} \mathrm{C}$.

Inoculum was prepared in $50 \mathrm{ml}$ of NB (Difco), sterilized at $121^{\circ} \mathrm{C}$ for $15 \mathrm{~min}$, in $250 \mathrm{ml}$ Erlenmeyer flask. The cultivation was shaken at $100 \mathrm{rpm}$ at $30^{\circ} \mathrm{C}$ for $24 \mathrm{~h}$. All experiments of this study, $1 \%$ inoculum was added to be $1 \times$ $10^{6} \mathrm{CFU} / \mathrm{ml}$ of medium.

\section{B. Biosurfactant Production and Extraction}

Pseudomonas spp. was cultured by using NB with $200 \mathrm{ml}$ working volume in $500 \mathrm{ml}$ Erlenmeyer flask at $30^{\circ} \mathrm{C}, 100$ rpm for $72 \mathrm{~h}$. The experiment was performed with triplication.

After cultivation, culture broth was centrifuged at $5500 \times \mathrm{g}$, $4^{\circ} \mathrm{C}$ for $15 \mathrm{~min}$ to collect cell-free culture broth (CFCB) and cell pellet.

The CFCB was then acidified to $\mathrm{pH} 2.0$ by $6 \mathrm{~N} \mathrm{HCl}$ and 
chilled overnight. The acidified $\mathrm{CFCB}$ was centrifuged at $7300 \times \mathrm{g}, 4^{\circ} \mathrm{C}$ for $20 \mathrm{~min}$ to collect the sediment. $6 \mathrm{~N} \mathrm{NaOH}$ was used to neutralize the sediment and then extracted with a mixture of chloroform:methanol (2:1) [9]. The organic phase was pooled and evaporated. Crude lipopeptide biosurfactant was purged with nitrogen gas to dryness and weighted.

The cell pellet was dried in hot air oven at $105^{\circ} \mathrm{C}$ until weight constant. The dried biomass was then weighted [10].

\section{Surface Tension (ST) Measurement}

To measure the ST, $40 \mathrm{ml}$ of CFCB were added into beaker and measured ST by tensiometer K6 (KRÜSS) with Du-Nouy Ring Method at $25^{\circ} \mathrm{C}$ [9] from triplicated experiments. Sterile NB and supplemented NB were used as controls.

\section{Effect of Carbon Sources and Ferrous Ion on Biosurfactant Production}

\section{1) Carbon Sources}

In this experiment, glucose (Difco) and molasses (50.47\% total sugar) were individually added into NB. Their supplement concentrations of glucose and molasses were 0.5 , 1.0 and $1.5 \% \mathrm{w} / \mathrm{v}$ of total sugar. The cultivation was incubated at $30^{\circ} \mathrm{C}, 100 \mathrm{rpm}$ for $72 \mathrm{~h}$. After cultivation period, culture broth was collected to analyze biomass, biosurfactant yield and ST.

2) Ferrous Ion

The culture medium with the highest biosurfactant yield from experiment 2.4.1 was selected to study effect of ferrous ion on biosurfactant production by Pseudomonas spp. $\mathrm{FeSO}_{4} \cdot 7 \mathrm{H}_{2} \mathrm{O}$ was added into medium to be the final concentrations of 50,100 and $500 \mu \mathrm{M}$. After $72 \mathrm{~h}$ cultivation at $30^{\circ} \mathrm{C}$ with $100 \mathrm{rpm}$, biomass, biosurfactant yield and ST were determined.

\section{E. Effect of Temperature and $\mathrm{pH}$ on Biosurfactant Production}

\section{3) Temperature}

The temperatures of $10,20,30$ and $40^{\circ} \mathrm{C}$ were used to culture Pseudomonas spp. with a selected ferrous concentration. The biomass, biosurfactant yield and ST were determined.

4) $\mathrm{pH}$

The culture temperature with the highest biosurfactant yield was used to vary initial culture medium $\mathrm{pH}$ of 5.0, 7.0 and 9.0. The biomass, biosurfactant yield and ST were also analyzed.

\section{F. Growth Kinetics of Pseudomonas spp. with Suitable Medium and Conditions}

Pseudomonas spp. was cultured in the glucose and ferrous supplemented medium and culture conditions with the maximum biosurfactant yield. The cell viability, ST and biosurfactant yield were monitored every $3 \mathrm{~h}$ for $72 \mathrm{~h}$. During exponential phase, the specific growth rate was determined [11].

\section{G. Experimental Design and Data Analysis}

The experiments of this study were performed in triplicate with completely randomized design. Data was calculated for analysis of variance. One way - ANOVA was used to analyze data with $95 \%$ significant level $(\alpha=0.05)$.

\section{RESUlTS AND DiSCUSSION}

\section{A. Effect of Molasses and Glucose}

All media of this experiment was able to culture Pseudomonas spp. and used to produce biosurfactant (Table I). The molasses supplement in NB showed the significant biomass increasing, but decreased biosurfactant yield. Molasses did not only significantly increase the biomass of bacterial cells, but it might also inhibit the biosurfactant production [10], [12]. The high biosurfactant yield was observed with 0.87 and $0.84 \mathrm{~g} / \mathrm{L}$, when Pseudomonas spp. was cultured in 0.5 and $1.0 \%$ glucose supplement, respectively. However, the ST of CFCB from $1.0 \%$ glucose supplement culture medium was significant lower than $0.5 \%$ glucose. Glucose is a good carbon source for organisms including microorganisms. It provides faster growth than other sugars, and is consumed first in sugar mixtures [8]. In contrast, high glucose concentration in the medium might inhibit the growth rate of microorganisms [8]. According to the results, the NB supplemented by $1 \%$ glucose was selected to use in the further experiments.

TABLE I: SURFACE TENSION VALUE OF CFCB, BIOMASS AND BIOSURFACTANT YIELD FROM PSEUDOMONAS SPP. WITH GLUCOSE AND MOLASSES SUPPLEMENT IN NB

\begin{tabular}{|c|c|c|c|}
\hline $\begin{array}{l}\text { Carbon } \\
\text { Sources }\end{array}$ & $\mathrm{ST}(\mathrm{mN} / \mathrm{m})$ & $\begin{array}{c}\text { Biomass } \\
(\mathrm{g} / \mathrm{L})\end{array}$ & $\begin{array}{c}\text { Biosurfactant Yield } \\
(\mathrm{g} / \mathrm{L})\end{array}$ \\
\hline NB (control) & $28.83 \pm 0.29^{a}$ & $0.77 \pm 0.02^{\mathrm{a}}$ & $0.58 \pm 0.01^{b}$ \\
\hline $\mathrm{NB}+0.5 \%$ Glucose & $37.17 \pm 1.04^{\mathrm{d}}$ & $1.02 \pm 0.01^{b c}$ & $0.87 \pm 0.06^{\mathrm{c}}$ \\
\hline $\mathrm{NB}+1.0 \%$ Glucose & $32.83 \pm 0.29^{c}$ & $0.97 \pm 0.03^{b}$ & $0.84 \pm 0.02^{\mathrm{c}}$ \\
\hline $\mathrm{NB}+1.5 \%$ Glucose & $32.33 \pm 0.76^{\mathrm{c}}$ & $1.12 \pm 0.05^{\mathrm{c}}$ & $0.06 \pm 0.01^{\mathrm{a}}$ \\
\hline $\mathrm{NB}+0.5 \%$ Molasses & $29.50 \pm 0.50^{\mathrm{ab}}$ & $1.75 \pm 0.13^{\mathrm{d}}$ & $0.16 \pm 0.09^{\mathrm{a}}$ \\
\hline $\mathrm{NB}+1.0 \%$ Molasses & $30.00 \pm 0.00^{b}$ & $1.90 \pm 0.04^{\mathrm{e}}$ & $0.06 \pm 0.03^{\mathrm{a}}$ \\
\hline $\mathrm{NB}+1.5 \%$ Molasses & $30.17 \pm 0.58^{b}$ & $2.18 \pm 0.06^{\mathrm{f}}$ & $0.08 \pm 0.10^{\mathrm{a}}$ \\
\hline
\end{tabular}

\section{B. Effect of Ferrous Ion}

TABLE II: SURFACE TENSION VALUE, BIOMASS AND BIOSURFACTANT YIELD FROM PSEUDOMONAS SPP. BY USING 1\% GLUCOSE IN NB WITH DIFFERENT CONCENTRATIONS OF FERROUS ION

\begin{tabular}{cccc}
\hline \hline $\begin{array}{c}\text { Ferrous Ion } \\
(\mu \mathrm{M})\end{array}$ & $\begin{array}{c}\text { Surface Tension } \\
(\mathrm{mN} / \mathrm{m})^{\mathrm{ns}}\end{array}$ & $\begin{array}{c}\text { Biomass } \\
(\mathrm{g} / \mathrm{L})\end{array}$ & $\begin{array}{c}\text { Biosurfactant Yield } \\
(\mathrm{g} / \mathrm{L})\end{array}$ \\
\hline 0 & $33.00 \pm 0.00$ & $\begin{array}{c}0.95 \pm \\
0.02^{\mathrm{b}}\end{array}$ & $0.84 \pm 0.01^{\mathrm{a}}$ \\
& $32.33 \pm 0.29$ & $\begin{array}{c}0.69 \pm \\
0.03^{\mathrm{a}}\end{array}$ & $1.55 \pm 0.02^{\mathrm{b}}$ \\
& & $0.64 \pm$ & \\
& $33.00 \pm 1.32$ & $0.02^{\mathrm{a}}$ & $1.58 \pm 0.07^{\mathrm{b}}$ \\
& & $0.65 \pm$ & \\
& $33.00 \pm 1.00$ & $0.01^{\mathrm{a}}$ & $2.08 \pm 0.12^{\mathrm{c}}$
\end{tabular}

The superscript of a,b,... with different letter in the same column is significantly difference $(p \leq 0.005)$.

The superscript of ${ }^{\text {ns }}$ with different values in the same column is significantly no difference $(p \leq 0.005)$.

Metal ions are the cofactor in living organisms. In this experiment, ferrous ion showed the remarkable effect on biosurfactant yield by Pseudomonas spp. (Table II). The maximum biosurfactant yield with $2.08 \mathrm{~g} / \mathrm{L}$ was derived by using $1 \%$ glucose in NB coupled with $500 \mu \mathrm{M} \mathrm{FeSO}$. The increase of biosurfactant yield was reported previously. Surfactin production of $B$. subtilis was increased 
approximately to $3.5 \mathrm{~g} / \mathrm{L}$, when added $2 \mathrm{mM} \mathrm{FeSO}_{4}$ into culture medium [6], [13]. To enhance biosurfactant production by $P$. aeruginosa, iron and other metal ions were supplemented in the media [14]. The raised biosurfactant by ferrous ion was not only presented by bacterial cultivations, but biosurfactant productions by Aspergillus ustus and Pleurotus djamor were also promoted by this ion [2], [15]. From the results, $1 \%$ glucose in NB coupled with $500 \mu \mathrm{M}$ $\mathrm{FeSO}_{4}$ was used for study of cultivation temperature.

\section{Effect of Cultivation Temperature}

Culture temperature caused effect on growth and bioprocessing by microorganisms. The cultivation of Pseudomonas spp. at $20^{\circ} \mathrm{C}$ by using $1 \%$ glucose in NB added with $500 \mu \mathrm{M} \mathrm{FeSO}_{4}$ represented the maximum biosurfactant yield of $2.39 \mathrm{~g} / \mathrm{L}$ (Table III). In contrast, the biosurfactant production was not observed at $40^{\circ} \mathrm{C}$, and ST was as same as control with $48 \mathrm{mN} / \mathrm{m}$. According to the biomass, temperature at $40^{\circ} \mathrm{C}$ might suppress Pseudomonas spp. growth. Kiran et al. [2] and Velioglu and Urek [15] also reported that temperature was a critical factor on microbial growth and biosurfactant production. On next experiment, Pseudomonas spp. was cultured at $20^{\circ} \mathrm{C}$ by using $\mathrm{NB}$ added with $500 \mu \mathrm{M} \mathrm{FeSO}_{4}$ as medium.

TABLE III: SURFACE TENSION VALUE, BIOMASS AND BIOSURFACTANT YIELD FROM PSEUDOMONAS SPP. BY USING 1\% GLUCOSE IN NB ADDED WITH $500 \mu \mathrm{M}$ FESO4 AT VARIOUS CULTURE TEMPERATURES

\begin{tabular}{|c|c|c|c|}
\hline $\begin{array}{c}\text { Culture } \\
\text { Temperature } \\
\left({ }^{\circ} \mathrm{C}\right)\end{array}$ & $\begin{array}{l}\text { Surface Tension } \\
\qquad(\mathrm{mN} / \mathrm{m})\end{array}$ & $\begin{array}{l}\text { Biomass } \\
(\mathrm{g} / \mathrm{L})\end{array}$ & $\begin{array}{l}\text { Biosurfactant Yield } \\
(\mathrm{g} / \mathrm{L})\end{array}$ \\
\hline 10 & $31.50 \pm 0.50^{\mathrm{a}}$ & $\begin{array}{l}0.80 \pm \\
0.02^{\mathrm{c}}\end{array}$ & $1.62 \pm 0.11^{a}$ \\
\hline 20 & $33.00 \pm 1.00^{\mathrm{ab}}$ & $\begin{array}{l}1.08 \pm \\
0.01^{\mathrm{d}}\end{array}$ & $2.39 \pm 0.09^{b}$ \\
\hline 30 & $50.17 \pm 0.76^{\mathrm{c}}$ & $\begin{array}{l}0.68 \pm \\
0.01^{\mathrm{b}}\end{array}$ & $2.07 \pm 0.09^{c}$ \\
\hline 40 & $48.50 \pm 0.50^{c}$ & $\begin{array}{l}0.04 \pm \\
0.01^{\mathrm{a}}\end{array}$ & N/A \\
\hline
\end{tabular}

The superscript of ${ }^{a, b}, \ldots$ with different letter in the same column is significantly difference $(p \leq 0.005)$.

N/A means no biosurfactant detected.

\section{Effect of $p H$}

The biomass and biosurfactant yield represented with the low values at initial pH 5 of Pseudomonas spp. cultivation by using $1 \%$ glucose in $\mathrm{NB}, 500 \mu \mathrm{M} \mathrm{FeSO}_{4}$ at $20^{\circ} \mathrm{C}$ (Table IV). The biomass from $\mathrm{pH} 7$ and 9 was not significantly different, but their biosurfactant yields were increased from 2.36 to $2.76 \mathrm{~g} / \mathrm{L}$, respectively. The result agreed with other reports [15]. For $P$. aeruginosa KVD-HR42, the biosurfactant production was raised by cultivation at $\mathrm{pH} 8.5$ [3]. The optimal $\mathrm{pH}$ for extracellular biosurfactant produced by Yarrowia lipolytica NCIM 3589 was 8.0 [16]. In contrast, the low $\mathrm{pH}$ culture medium was suitable for biosurfactant production by fungi [2], [15].

\section{E. Pseudomonas spp. Growth Kinetics}

When Pseudomonas spp. was cultured in NB supplemented with $1.0 \%$ w/v glucose, $500 \mu \mathrm{M} \mathrm{FeSO}_{4}$, pH 9.0 at $20^{\circ} \mathrm{C}$ for $72 \mathrm{~h}$, the surface tension was significantly decreased at the exponential growth phase (Fig. 1). After $24 \mathrm{~h}$ culture time, the surface tension was mostly constant at 30 $\mathrm{mN} / \mathrm{m}$. The result was agreed with $P$. aeruginosa MA01 [17] and Candida albicans [18]. Also, Rufino et al. [19] reported that $C$. lipolytica UCP0988 produced rufisan biosurfactant during exponential growth phase. By this medium and culture conditions, the biosurfactant yield was enhanced up to $2.76 \mathrm{~g} / \mathrm{L}$. While biosurfactant yield from NB was $0.58 \mathrm{~g} / \mathrm{L}$. During exponential phase, the specific growth rate of Pseudomonas spp. was $0.25 \mathrm{~h}^{-1}$.

TABLE IV: SURFACE TENSION VALUE, BIOMASS AND BIOSURFACTANT YIELD FROM PSEUDOMONAS SPP. BY USING $1 \%$ GLUCOSE IN NB, $500 \mu \mathrm{M}$ FESO4 AT $20^{\circ} \mathrm{C}$ WITH DIFFERENT INITIAL PHS

\begin{tabular}{cccc}
\hline \hline $\mathrm{pH}$ & $\begin{array}{c}\text { Surface Tension } \\
(\mathrm{mN} / \mathrm{m})\end{array}$ & $\begin{array}{c}\text { Biomass } \\
(\mathrm{g} / \mathrm{L})\end{array}$ & $\begin{array}{c}\text { Biosurfactant } \\
\text { Yield }(\mathrm{g} / \mathrm{L})\end{array}$ \\
\hline \multirow{2}{*}{5.0} & $32.67 \pm$ & $0.64 \pm$ & $0.03 \pm 0.01^{\mathrm{a}}$ \\
& $1.15^{\mathrm{b}}$ & $0.03^{\mathrm{a}}$ & \\
& $31.50 \pm$ & $1.06 \pm$ & $2.36 \pm 0.06^{\mathrm{b}}$ \\
& $0.50^{\mathrm{ab}}$ & $0.03^{\mathrm{b}}$ & \\
& $30.67 \pm$ & $1.08 \pm$ & $2.76 \pm 0.03^{\mathrm{c}}$ \\
\hline
\end{tabular}

The superscript of ${ }^{\mathrm{a}, \mathrm{b}, \ldots}$ with different letter in the same column is significantly difference $(p \leq 0.005)$.

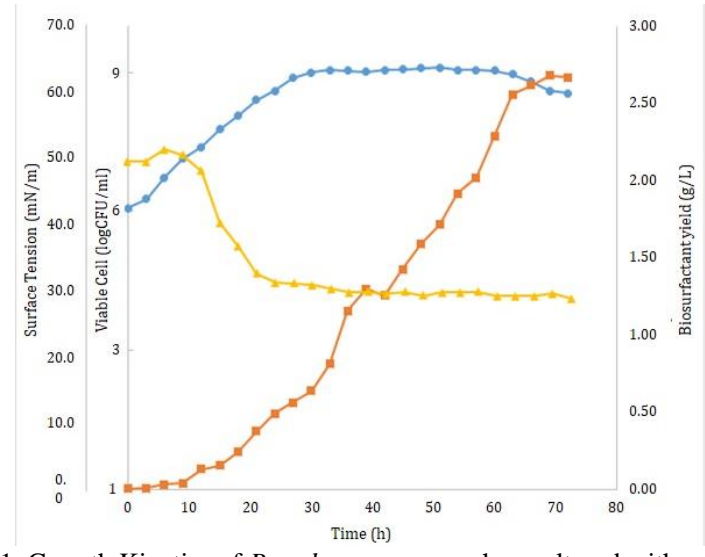

Fig. 1. Growth Kinetics of Pseudomonas spp. when cultured with selected conditions. ST (triangle), Viable cell (circle) and Biosurfactant yield (square).

\section{CONCLUSION}

The effects of NB supplemented by carbon sources and ferrous ion, temperature and initial $\mathrm{pH}$ were investigated to enhance the biosurfactant production form Pseudomonas spp. with single factor experimental design. Its biosurfactant yield was increased with 4.5 times when cultured by using NB supplemented with $1.0 \%$ w/v glucose, $500 \mu \mathrm{M} \mathrm{FeSO}_{4}, \mathrm{pH}$ 9.0 at $20^{\circ} \mathrm{C}$. Furthermore, Pseudomonas spp. will be carried out for chemical structure identification and investigation on biological activity of its biosurfactant.

\section{ACKNOWLEDGMENT}

The authors gratefully acknowledge the financial support provided by Thammasat University under the TU Research Scholar, Contact No. 1/12/2560 and the support of Thailand Research Fund, Office of Higher Education Commission, and Thammasat University under grant number MRG5680146.

\section{REFERENCES}

[1] F. E. Mouafi, M. M. A. Elsoud, and M. E. Moharamb, "Optimization of biosurfactant production by Bacillus brevis using response surface methodology," Biotechnology Reports, vol. 9, pp. 31-37, 2016. 
[2] G. S. Kiran, T. A. Hema, R. Gandhimathi, J. Selvin, T. A. Thomas, T. R Ravji, and K. Natarajaseenivasan, "Optimization and production of a biosurfactant from the sponge-associated marine fungus Aspergillus ustus MSF3," Colloids and Surfaces B: Biointerfaces, vol. 73, pp. 250-256, 2009.

[3] K. V. Deepika, S. Kalam, P. R. Sridhar, A. R. Podile, and P. V. Bramhachari, "Optimization of rhamnolipid biosurfactant production by mangrove sediment bacterium Pseudomonas aeruginosa KVD-HR42 using response surface methodology," Biocatalysis and Agricultural Biotechnology, vol. 5, pp. 38-47, 2016.

[4] S. R. Mutalik, B. K. Vaidya, R. M. Joshi, K. M. Desai, and S. N. Nene, "Use of response surface optimization for the production of biosurfactant from Rhodococcus spp. MTCC 2574," Bioresource Technology, vol. 99, pp. 7875-7880, 2008.

[5] S. N. Al-Bahry, Y. M. Al-Wahaibi, A. E. Elshafie, A. S. Al-Bemani, S. J. Joshi, H. S. Al-Makhmari, and H. S. Al-Sulaimani, "Biosurfactant production by Bacillus subtilis B20 using date molasses and its possible application in enhanced oil recovery," International Biodeterioration and Biodegradation, vol. 81, pp. 141-146, 2013.

[6] Y. H. Wei and I. M. Chu, "Enhancement of surfactin production in iron-enriched media by Bacillus subtilis ATCC 21332," Enzyme and Microbial Technology, vol. 22, pp. 724-728, 1998.

[7] G. S. Kiran, T. A. Thomas, J. Selvin, B. Sabarathnam, and A. P. Lipton, "Optimization and characterization of a new lipopeptide biosurfactant produced by marine Brevibacterium aureum MSA13 in solid state culture," Bioresource Technology, vol. 101, pp. 2389-2396, 2010.

[8] B. Hemlata, J. Selvin, and K. Tukaram, "Optimization of iron chelating biosurfactant production by Stenotrophomonas maltophilia NBS-11," Biocatalysis and Agricultural Biotechnology, vol. 4, pp. 135-143, 2015.

[9] M. S. N. Ayudhya, P. Chuenchomrat, and P. Sutthirak, "Screening and characterization of bacterial biosurfactant from Bangkok and vicinities," International Journal of Life Sciences Biotechnology and Pharma Research, vol. 4, pp. 168-171, 2015.

[10] S. Joshi, C. Bharucha, S. Jha, S. Yadav, A. Nerurkar, and A. J. Desai, "Biosurfactant production using molasses and whey under thermophilic conditions," Bioresource Technology, vol. 99, pp. 195-199, 2008.

[11] M. Berney, H. U. Weilenmann, J. Ihssen, C. Bassin, and E. Thomas, "Specific growth rate determines the sensitivity of Escherichia coli to thermal, UVA, and solar disinfection," Applied and Environmental Microbiology, vol. 72, no. 4, pp. 2586-2593, 2006.

[12] R. M. Patel and A. J. Desai, "Biosurfactant production by Pseudomonas aeruginosa GS3," Letters in Applied Microbiology, vol. 25, pp. 91-94, 1997.

[13] Y. H. Wei, L. F. Wang, J. S. Chang, and S. S. Kung, "Identification of induced acidification in iron-enriched cultures of Bacillus subtilis during biosurfactant fermentation," Journal of Bioscience and Biotechnology, vol. 96, no. 2, pp. 174-178, 2003.

[14] L. Zhi, Y. Xing-zhong, Z. Hua, Z. Guang-ming, L. Zhi-feng, M. A. Xiao-ling, and Z. Ya-ying, "Optimizing rhamnolipid production by Pseudomonas aeruginosa ATCC 9027 grown on waste frying oil using response surface method and batch fed fermentation," Journal of Central South University, vol. 20, pp. 1015-1021, 2013.

[15] Z. Velioglu and R. O. Urek, "Optimization of cultural conditions for biosurfactant production by Pleurotus djamor in solid state fermentation," Journal of Bioscience and Bioengineering, vol. 120, no. 5, pp. 526-531, 2015.

[16] S. S. Zinjarde and A. Pant, "Emulsifier from tropical marine yeast, Yarrowia lipolytica NCIM 3589," Journal of Basic Microbiology, vol. 42, pp. 67-73, 2002.

[17] H. Abbasi, M. M. Hamedi, T. B. Lotfabad, H. S. Zahiri, H. Sharafi, F. Masoomi, A. A. Moosavi-Movahedi, A. Ortiz, M. Amanlou, and K. A. Noghabi, "Biosurfactant-producing bacterium, Pseudomonas aeruginosa MA01 isolated from spoiled apples: physicochemical and structural characteristics of isolated biosurfactant," Journal of Bioscience and Bioengineering, vol. 113, no. 2, pp. 211-219, 2012.

[18] F. R. Accorsini, M. J. R. Mutton, E. G. M. Lemos, and M. Benincasa, "Biosurfactants production by yeasts using soybean oil and glycerol as low cost substrate," Brazilian Journal of Microbiology, vol. 52, pp. $116-125,2012$.

[19] R. D. Rufino, J. M. Luna, G. M. C. Takaki, and L. A. Sarubbo, "Characterization and properties of the biosurfactant produced by Candida lipolytica UCP 0988," Electronic Journal of Biotechnology, vol. 17, 34-38, 2014.

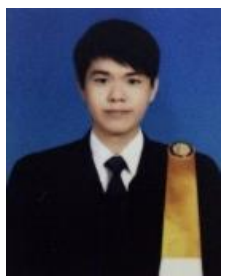

Thanawat Choopraserdchok was born in Bangkok, Thailand. He was born on October 14, 1992. He was graduated in B.Sc. (food science and technology) with first class honor in June 2015 from the Department of Food Science and Technology, Faculty of Science and Technology, Thammasat University. Now he is graduated student and studying in the Master Degree of Food Science and Technology on the major of Food Microbiology. His thesis was focused on effect of carbon sources, ferrous ion and culture conditions on lipopeptide biosurfactant production by Pseudomonas spp

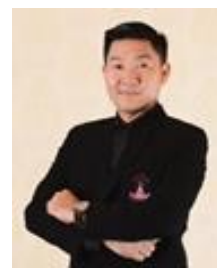

Dusit Athinuwat is a lecturer at the Department of Agricultural Technology, Faculty of Science and Technology, Thammasat University (Rangsit Campus), Thailand. He is plant pathologist who working on plant pathogen genome, plant-pathogen interaction, and screening of antagonistic microorganisms against plant pathogens. His research articles were also published in Phytopathology, An International Journal of The American Phytopathological Society and PLOS ONE, the world's first multidisciplinary Open Access journal.

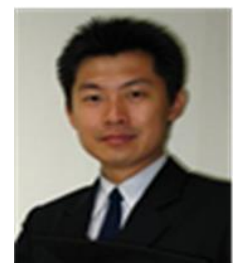

Pumnat Chuenchomrat is a lecturer at the Department of Food Science and Technology, Faculty of Science and Technology, Thammasat University (Rangsit Campus), Thailand. $\mathrm{He}$ is working on screening of biosurfactant producing microorganisms and antimicrobial and anti-adhesion activities of biosurfactants against foodborne pathogens. He has been a committee of The Congress on Science and Technology of Thailand since 2010. His research articles were also published in ScienceAsia, International Journal of Life Sciences Biotechnology and Pharma Research and The Congress on Science and Technology of Thailand. 